\title{
TAX EVASION THROUGH SETTLEMENT OPTIONS: ANOTHER DEFEAT FOR SUBSTANTIAL OWNERSHIP IN ESTATE TAXATION*
}

THE Federal Estate Tax is a progressive ${ }^{1}$ excise tax ${ }^{2}$ on the right to transmit property at death. ${ }^{3}$ It is imposed on the taxable estate ${ }^{4}$ of a decedent, which is computed by subtracting the deductions and exemptions of Sections $2051-2056^{5}$ from the gross estate determined by Sections 2031-2044. Section 2033 provides for the inclusion of a decedent's property to the extent of his interest at the time of his death. ${ }^{7}$ Section 2041 provides for the in-

*Second National Bank of Danville, Ill. v. Dallman, 209 F.2d 321 (7th Cir. 1954).

1. INT. Rev. CoDE of 1954, § 2001; INT. REv. Code of 1939, §§ 810, 935. For cxample: the tax on a taxable estate of less than $\$ 5,000$ is $3 \%$ of the taxable estate; on a taxable estate of over $\$ 250,000$, but not over $\$ 500,000$, it is $\$ 65,7000$, plus 32\% of the excess over $\$ 250,000$; on a taxable estate of over $\$ 10,000,000$, the tax is $\$ 6,088,200$, plus $77 \%$ of the excess over $\$ 10,000,000$.

2. New York Trust Co. v. Eisner, 256 U.S. 345 (1921); 1 PAU,, Fedesal Estate and GIFT Taxation $\$ 1.06$ (1942); cf. Scholey v. Rew, 23 Wall. 331 (U.S. 1874) (succession tax); Knowiton v. Moore, 178 U.S. 41 (1900) (inheritance tax).

3. Ithaca Trust Co. v. U.S., 279 U.S. 151 (1929); Y.MI.C.A. v. Davis, 264 U.S. 47 (1924) ; Edwards v. Slocum, 264 U.S. 61 (1924); Knowiton v. Moore, 178 U.S. 41 (1900).

4. The term "taxable estate" replaces the term "net estate" used in the 1939 Code. It is defined in INT. REv. CODE of 1954, § 2051 as follows: "For purposes of the tax imposed by section 2001, the value of the taxable estate shall be determined by dedueting from the value of the gross estate the exemption and deductions provided for in this part."

5. Int. Rev. CODE of 1954, \$\$ 2051-2056; INT. REv. Code of 1939, \& 812. In addition to the specific exemption of $\$ 60,000$, the major deductions are: claims against, and expenses of, the estate; losses of the estate not covered by insurance; property previcusly taxed; transfers for public, charitable and religious purposes; and transfers to surviving spouses to the extent of $50 \%$ of the value of the adjusted gross estate.

6. INT. Rev. CODE of 1954, §§ 2031-2044; INT. REv. CODE of 1939, § 811. In addition to the provisions of $\S 2033$ (see note 7 infra) and $\S 2041$ (see notes 8 and 9 infru) the sections provide for the inclusion of dower and courtesy interests, transfers in contemplation of death, transfers with income retained, transfers effective at death, transfers with power to change enjoyment, annuities, joint interests, insurance, and transfers for insufficient consideration.

7. Int. Rev. Code of 1954, § 2033; Int. Rev. Cone of 1939, § 811(a). Examples of the variety of interests covered are: interests in a trust corpus, Equitable Trust Co. of New York, 31 B.T.A. 329, rev'd on other grounds sub nom. Commissioner v. Chase National Bank, S2 F.2d 157 (2d Cir.), cert. denied, 299 U.S. 552 (1936) ; accrued but unpaid annuity payments, ibid.; dividends declared but not yet collected at the time of death, Estate of M. J. Corbett, 12 T.C. 163 (1949); notes or other choses in action owned by decedent, Estate of G. Percy McGlue, 41 B.T.A. 1199 (1940), even if cancelled by will, U.S. Treas. Reg. 105, § $\$ 1.13$ (1952); remainders if vested and not extinguished by decedent's death, Frazier's Estate v. Commissioner, 162 F.2d 167 (3rd Cir. 1947). For other examples see 1 PaUl, Federal Estate and Gifi Taxation, $\$ 4.03$ (1942); $I d$. $\S 4.03$ (Supp. 1946).

Property held as trustee is not included. Reed v. Commissioner, 36 F.2d 867 (5th Cir. $1930)$; U.S. Treas. Reg. 105, $\$ \$ 1.13$ (1952). Interests extinguished by the death of the decedent are also excluded. Commissioner v. Rosser, $64 \mathrm{~F} .2 \mathrm{~d} 631$ (3rd Cir. 1941). 
clusion of property subject to a general power of appointment by the clecedent; $;$ however, if the power was created prior to 1942 , it is taxable only if exercised. ${ }^{9}$

The Commissioner recently attempted to broaden the scope of these sections in Second National Bank of Danville, Ill. v. Dallman. ${ }^{10}$ In 1912 decedent's father purchased a $\$ 30,000$ life insurance policy naming the clecedent as beneficiary. The settlement option elected by the insured provided that upon the death of the insured, the company was to make yearly payments of three percent of the face amount to the beneficiary for life. Decedent had no right to surrender the policy for its cash value, ${ }^{11}$ but she did have the power to name a contingent beneficiary to take the principal amount upon her death. ${ }^{12}$ In

8. INT. Rev. CODE of 1954, § 2041 and INT. Rev. CODE of 1939, § 811(f): "The value of the gross estate shall include ... (2) Powers Created after October 21, 1942.To the extent of any property with respect to which the decedent has at the time of his death a general power of appointment created after October 21, 1942, or with respect to which the decedent has at any time exercised or released such a power of appointment by a disposition which is of such nature that if it were a transfer of property owned by the decedent, such property would be includible in the decedent's gross estate under sections 2035 to 2038 , inclusive."

9. Int. Rev. CODE of 1954, §2041 and INT. Rev. Code of 1939, §811(f): “(a) In General.-The value of the gross estate shall include ... (1) Pozecrs of Appointmont Created on or before October 21, 1942.-To the extent of any property with respect to which a general power of appointment created on or before October 21, 1942, is excrciscd by the decedent-(A) by will, or (B) by a disposition which is of such nature that if it were a transfer of property owned by the decedent, such property would be included in decedent's gross estate under sections 2035 to 2038 inclusive; . . . (b) Definitions.-For the purposes of subsection (a)-(1) General Power of Appointment.-The term 'general power of appointment' means a power which is exercisable in favor of the decedent, his estate, his creditors, or the creditors of his estate."

This section was completely rewritten by the Powers of Appointment Act of 1951, 65 STAT. 91 (1951), and reenacted without substantive change in the Internal Revenue Code of 1954. Under the 1951 Act, property subject to a general power created beforc October 21,1942 , is included in the gross estate if the decedent exercised the power. The further requirement that the property pass under the power, established by Helvering $v$. Grinnell, 294 U.S. 153 (1935), was eliminated. Wilson v. Kraemer, 190 F.2d 341 (2nd Cir.), cert. denied, 342 U.S. 859 (1951) ; Moran's Estate, 16 T.C. 814 (1951) ; H.R. REp. No. 327, 82d Cong., 2d Sess. 4 (1951). The Court in the principal case cited the requirement of the property passing as still necessary for pre-1942 powers, but this appears erroneous. For the history of taxation of powers see, Craven, Powers of Appointment Act of 1951, 65 Harv. L. Rev. 55 (1951).

10. 209 F.2d 321 (7th Cir. 1954).

11. Transcript of Record, p. 16, Second National Bank of Danville, Ill. v. Dallman, 209 F.2d 321 (7th Cir. 1954). Typewritten on the policy was this provision: "By recluest of the insured, settlement of this policy is to be made in accordance with the provisions of Option "A" without privilege of surrender."

12. Ibid.: ". . . the Beneficiary or Beneficiaries if of lawful age when this Policy becomes payable, shall also . . . have the right, with the privilege of revocation and change, to designate a Contingent Beneficiary or Beneficiaries whose interest shall be expressed in, or endorsed by the Company on, this Policy; provided, however- . . 2nd. No election, direction, designation, revocation or change shall be effective unless duly made in writing and filed at the Home Office of the Company (accompanicd by the Policy for suitable endorsement) prior to or at the time this Policy shall become payable." 
default of such appointment, the principal was to be paid to her "executors, administrators or assigns." 13 After the death of the insured in 1925, interest payments were made to decedent until her death in 1945. As she had not exercised her right to name a contingent beneficiary, the fund was paid to her executor, who in turn paid it to a trust established by the residuary clause of decedent's will. ${ }^{14}$ The Commissioner included the fund in decedent's gross estate under Sections 2033 and 2041, and the district court affirmed this action without opinion. ${ }^{15}$

Upon appeal by the taxpayer, the government contended that decedent had held a combination of rights over the principal sufficient to create an "interest" within the meaning of Section 2033.10 It argued that since she

13. Ibid.: "5th. At the death of the last surviving Beneficiary, if there then be no Contingent Beneficiary then living ... the amount retained by the Company under Option "A" will be paid to the executors, administrators, or assigns of such last surviving Beneficiary . . . upon due surrender of this Policy; ....."

14. Decedent's will made no mention of the insurance procecds but contained a residuary clause as follows: "All the rest, residue and remainder of my estate, whether real, personal or mixed, including the proceeds of the sale of the property above mentioned, I give, devise and bequeath to the Second National Bank of Danville, Illinois, in trust, however, for the following uses and purposes. ..." The trust was for the benefit of the two surviving heirs of the decedent. Second National Bank of Danville, Ill. v. Dallman, 209 F.2d 321, 322-3 (7th Cir. 1954).

15. Transcript of Record, pp. 21-2, Second National Bank of Danville, Ill. v. Dallman, 209 F.2d 321 (7th Cir. 1954).

Upon decedent's death the insurance company paid her executor $\$ 30,437.50$ representing the face amount of $\$ 30,000$ plus $\$ 437.50$ accrued but unpaid annuity. The estate tax return filed by the executor mentioned but did not include the payment in the gross estate. The Tax Collector then notified the executor that a determination had been made that the payment should have been included in the gross estate and demanded payment of a tax deficiency of $\$ 8,400.75$ plus $\$ 690$ interest. The executor paid the assessment under protest and then brought an action against the Tax Collector in the district court for a refund. Id. at 9-12. Upon appeal the taxpayer apparently conceded that the accrued but unpaid annuity was properly included in the gross estate for only the face amount of $\$ 30,000$ was in issue upon appeal.

16. Brief for Appellee, pp. 16-29, Second National Bank of Danville, Ill. v. Dallman, 209 F.2d 321 (7th Cir. 1954). The government suggested that decedent had a life estate in the $\$ 30,000$. And since the remainder was to her "executors, administrators or assigns" it was hers by analogy to the Rule in Shelley's Case. The two interests were then merged to give decedent the fee. The Rule in Shelley's Case is still in force in Illinois. Baker v. Scott, 62 Ill. 86 (1871); Cook v. Sober, 302 Ill. 498, 135 N.E. 601 (1922); see also, People v. Emery, 314 Ill. 220, 223, 145 N.E. 349, 350 (1924). But since in order to find a life estate in the decedent it is necessary to construe the settlement option as creating a trust, see note 25, infra, the Rule in Shelley's Case would not apply; for the life estate would be equitable and the remainder legal. See, e.g., People v. Emery, 314 III. $220,223,145$ N.E. 349,350 (1924) ; Lord v. Comstock, 240 Ill. 492, 500, $8 S$ N.E. 1012, 1015 (1909); Sires, The Law of Future Ixterests, 125 (1936). Apparently, for this reason, the government did not press this argument. In summing up its argument under $\S 2033$, the government stated: "Clearly, the interest of the decedent in the insurance proceeds here involved was more than the interest of a life tenant with a power of appointment, as contended by appellant. Furthermore, regardless of what terminology may be used to describe her interest, it is settled that the federal taxing statutes are concerned 
could have sold her interest in the income from the fund and her "remainder"17 interest in the principal itself for an amount substantially equivalent to $\$ 30,000$, she had had virtual ownership of the fund during her lifetime. ${ }^{18}$ And, since the principal was paid to her estate, the government argued that decedent had possessed the power to dispose of the fund by will, which power she exercised. ${ }^{10}$ Prior decisions ${ }^{20}$ rejecting similar substantial ownership arguments were distinguished on the ground that, in the instant case, decedent's substantial ownership during her lifetime was followed by full title in her estate; $; 1$ in the prior cases, the incidents of ownership had been extinguished by decedents' deaths, and the remainder interests had passed to third parties. ${ }^{22}$

Alternatively, the government argued that since the principal passed to ultimate beneficiaries according to decedent's will, the fund was taxable under Section 2041 as property passing under a general power of appointment exercised by the the decedent. ${ }^{23}$

The Seventh Circuit rejected both of the government's contentions and reversed the court below. It held that decedent had never had a remainder interest in the principal and that her entire interest in the fund was extinguished by her death. ${ }^{24}$ Apparently the court felt that the insurance contract had not created a trust, and that without a trust only a contractual right as opposed to a remainder interest came into existence. ${ }^{25}$ It rejected the government's sub-

with realities, not with technical refinements of title." Brief for Appellee, p. 27, supra (emphasis added).

17. See note 16 supra, and note 25 infra.

18. Brief for Appellee, pp. 24-7, Second National Bank of Danville, Ill. v. Dallman, 209 F.2d 321 (7th Cir. 1954).

1.9. Id. at $29-30$.

20. Estate of Haggett, 14 T.C. 325 (1950) (decedent had in effect a privilege of surrender for the discounted cash value of an annuity plus a general power of appointment over the unpaid balance at her death, with a remainder over to her grandchildren); Estate of Schwartz, P-H 1947 TC MEM. DEC. đf 47,034 (1947) (decedent was life beneficiary of an annuity contract purchased by her husband and had the right to change the beneficiary, to obtain the cash surrender value of the contract, and to assign the policy, with the balance of payments to go to her husband as default taker upon her death); Davis v. United States, 27 F. Supp. 698 (S.D.N.Y. 1930) (decedent had a limited power of sale over trust corpus, and a contingent remainder interest).

21. Brief for Appellee, pp. 24-7, Second National Bank of Danville, Ill. v. Dallman, 209 F.2d 321 (7th Cir. 1954). There seem to be no prior decisions in which the remainder passed to the decedent's estate as in the instant case.

22. See note 20 supra.

23. See notes 8 and 9 supra.

24. Second National Bank of Danville, Ill. v. Dallman, 209 F.2d 321, 325 (7th Cir. 1954).

25. No remainder can be created without a precedent estate which is said to support it. Stoller v. Doyle, 257 Ill. 369, 374, 100 N.E. 959, 961 (1913). If the insurance contract did not create a trust, the $\$ 30,000$ held by the company was in the form of a loan and not a legal life estate. Though the prevailing view is that settlement options create debtor-creditor relationships between the insurance companies and the bencficiaries, Holmes v. John Hancock Mutual Life Ins. Co., 288 N.Y. 106, 41 N.E.2d 909 (1942); Tate v. Hain, 181 Va. 402, 25 S.E.2d 321 (1943); Pierowich v. Metropolitan Life Ins. 
stantial ownership argument, finding the grounds offered for distinguishing prior decisions insufficient. ${ }^{26}$ And it held that decedent did not have a testamentary general power of appointment because the insurance contract did not specifically create such a power. ${ }^{27}$

Co., 282 Mich. 118, 275 N.W. 789 (1937); VANCE, INstrance, $\$ 119$ (3rd ed. 1951), it is not completely clear that Illinois follows the majority rule on this point. An Illinois statute dealing with settlement options allows insurance companies to mingle funds held in "trust or other arrangements" suggesting that trusts are created in some types of settlement options. ILL. Rev. Stat. c. 73, §853 (Bar Ass'n ed. 1953). And in 1935, an Illinois Appellate Court held that an insurance settlement created a trust. Holowaty v. Prudential Life Ins. Co., 282 III. App. 584 (1935). But the Illinois Supreme Court, when faced with a similar settlement option, discussed the case in terms of a debtorcreditor relationship; however they reached the same result as did the Holowaty case: the insurance payments could not be reached by creditors under the Illinois garnishment statute. Roth v. Kaptowsky, 393 Ill. 4S4, 66 N.E.2d 664 (1946). In Hughes v. Sun Life Assur. Co. of Canada, 159 F.2d 110 (7th Cir. 1946), the court, citing the Roth case, held that under Illinois law a settlement option did not create a trust, where the question was the ultimate incidence of the estate tax.

26. The court stated that decedent's economic dominion over the fund was less than that held by the decedent in Haggett, see note 20 stpra. But this avoids the main thrust of the government's argument, which was that the payment to decedent's estate in default of appointment distinguishes the instant case from both Haggett and the decision upon which it was based, Helvering v. Safe Deposit \& Trust Co., 316 U.S. 56 (1942). See notes 36-9 infra and accompanying text.

27. The court held that decedent's right to name a contingent beneficiary did not constitute a general power of appointment. Second National Bank of Danville, IIl. v. Dallman 209 F.2d 321, 323 (7th Cir. 1954). The court did not discuss its reasons for so holding; and it is difficult to see on what grounds the holding was based. The right was not limited in any way, see note 12 stpra, and clearly was exercisable in favor of decedent's estate, her creditors or the creditors of her estate; it would thus appear to be within the definition of a general power given in INr. REv. CovE of 1954, § 2041 (b) (1). See note 9 supra. The right, if exercised, would certainly be a "disposition which is of such nature that if it were a transfer of property owned by the decedent, such property would be includible in the decedent's gross estate under sections 2035 to sections 2038 inclusive ...," INT. REv. CODE OF 1954, § 2041 (a) (1) (B), as a transfer effective at death. But since this right was not exercised, the government conceded that it did not afford a basis for taxation. See note 9 supra.

The real question raised by the government was whether decedent's power of disposal over her estate gave her, in effect, a general power of appointment over property paid into her estate. The court did not meet this question squarely. It is difficult to follow the court's reasoning on this point, but it appears to be as follows: the right to make a disposition of property, testamentary or otherwise, by power of appointment, must derive from the donor, Second National Bank of Danville, Ill. v. Dallman, 209 F.2d 321, 324 (7th Cir. 1954); the right of testamentary disposition over one's estate is created by statute; thus a donor giving or devising property to the estate of another does not grant the power to dispose of the property to the donee. This reasoning is strictly verbal: it states in effect that there is a real difference between granting a person the power to dispose of property and placing the property in a position where the person will be able, by virtue of some pre-existing power, to dispose of it. It is well settled that powers can be created by implication. E.g., Matter of Thompson, 274 App. Div. 49, 80 N.Y.S.2d 1 (1st Dept. 1948) ; Bowerman, Adm'r. v. Bowerman, 67 Ohio App. 425, 35 N.E.2d 1012 (1941) ; McKallip's Estate, $324 \mathrm{~Pa}$ 438, 188 Atl. 343 (1936). The real problem is whether 
This decision raises an unwarranted distinction for tax purposes between contract rights of a decedent and those of his estate. ${ }^{28}$ If the insurance contract had provided that the company was to retain the fund for a period of time and then pay it to decedent, her executors, administrators or assigns, the fund would clearly have been includible in her gross estate even though she died before payment was due. ${ }^{29}$ Yet decedent's economic benefits from such an arrangement would be no greater than those in the instant case. ${ }^{30}$ Moreover, Congress has specifically taxed other contractual rights to which a decedent has no claim, and which have been created by third parties in favor of deced-

or not a party who has practical control over the devolution of property after his death has a testamentary power of appointment within the meaning of $\S 2041$ of the estate tax. See notes 43-6 infra and accompanying text.

The court suggested that the executor's action in paying the fund over to the trust created by the residuary clause was improper, but held that, in any event, what he did with the property once he received it is irrelevant. Second National Bank of Danville, IIl. v. Dallman, 209 F.2d 321, 326 (7th Cir. 1954). It is not clear in what respect the court questioned the propriety of the executor's action. It seems doubtful that the Court was suggesting that the fund should not have passed under the residuary clause. The words "executors, administrators or assigns of $\mathrm{A}$ " are usually contrued to mean the estate of A. Hamilton v. Darley, 266 Ill. 542, 107 N.E. 798 (1915) ; Pietri v. Seguenot, 96 Mo. App. 258, 69 S.W. 1055 (1902). It is also well established that a residuary clause covers everything in an estate not specifically devised after creditors' claims are met. E.g., In re Hartwig's Estate, 70 Idaho 77, 211 P.2d 399 (1949) ; In the Matter of Estate of Bumstead, 1 N.J. 386, 64 A.2d 55 (1949); Wood's Estate, 209 Pa. 16, 57 Atl. 1103 (1904); Atkinson, Wilts 736 (2d ed. 1953). It appears from the Transcript of the Record, though it is not specifically stated, that the executor paid the fund to the trust directly upon its receipt instead of merging it with the other assets of the estate until the final winding up of the estate. It might be that the court is referring to this. But, unless the estate was otherwise insolvent, the error was a technical one of no practical consequence. And the estate in the instant case was solvent.

28. This refers, of course, to contracts to pay which are in existence prior to the death of the decedent. In the instant case, for example, the insurance company was bound by contract to pay to decedent's estate the face amount of the policy in default of appointment, and this obligation was in existence during the lifetime of the beneficiary.

29. E.g., Du Val's Estate v. Commissioner, 152 F.2d 103 (9th Cir. 1945), cirt. denied, 328 U.S. 838 (1946); Parrott v. Commissioner, 30 F.2d 792 (9th Cir. 1929); Estate of G. Percy McGlue, 41 B.T.A. 1199 (1940).

30. Of course where the contract is to pay the person at some future time, there is a possibility that the person will live until payment. But since in either case the person can sell the right to receive payment in the future, this makes little practical difference. In the case of a contract to pay decedent's estate, the sale of the right would be in the form of a contract to will and the purchaser would be faced with the risk of insolvency of the estate as well as the risk of insolvency of the debtor. However, this is a matter of valuation and not a difference in kind. Since actuarial tables can be used to determine the life expectancy of a person, there is little more difficulty in estimating the value of the right to receive a fixed sum upon the death of a person than in estimating the value of the right to receive a fixed sum at a given date in the future.

The Connecticut Supreme Court has recently held that a sum owed to the estate of a decedent, under a contract made between payor and executor of decedent's husband's estatc, was property owned by the decedent for the purposes of the Connecticut Personal Property Tax. Stirling v. Connelly, 107 A.2d 274 (Conn. 1954). 
ent's estate. It has done so by including the "amount receivable by the executor as insurance... on the life of the decedent" even though the policy is taken out and completely paid for by someone other than the insured. ${ }^{31}$ Furthermore, Congress has decreed that property is part of decedent's gross estate if subject to a power which decedent may exercise only in favor of his own estate. ${ }^{32}$

The court's reasoning in Second National appears dominated by "elusive and subtle casuistries" of property law which should be irrelevant for tax purposes. $^{33}$ Decedent held a combination of rights over the principal which gave her as much economic dominion as if she had held the fund in fee simple; under the substantial ownership test used in applying Section 61 of the Internal Revenue Code, ${ }^{35}$ decedent was the owner of the fund. Although this test has not been used heretofore in construing Section 2033, the Supreme Court decision, ${ }^{36}$ relied upon by lower courts in rejecting substantial ownership argu-

31. INT. Rev. CODE of 1954, § 2042; INT. Rev. CODE of 1939, § \$11(g). U.S. Treas. Reg. 105, § $\$ 1.26$ (1942).

32. INT. REv. CoDE of 1954, \$ 2041 (a) (1). In so doing, Congress has recognized that the power to appoint to one's own estate is equivalent to the ability to appoint to one's self. See MTorgan v. Commissioner, 309 U.S. 78, 81-2 (1940).

33. Justice Frankfurter clearly recognized this principle in speaking for the majority in Helvering v. Hallock, 309 U.S. 106, 118 (1940): "The importation of these distinctions and controversies from the law of property into the administration of the estate tax preeludes a fair and workable tax system. Essentially the same interests, judged from the point of view of wealth, will be taxable or not, depending upon elusive and subtle casuistries which may have their historic justification but possess no relevance for tax purposes. These unwitty diversities of the law of property derive from medieval concepts as to the necessity of a continuous seisin. Distinctions which originated under a feudal economy when land dominated social relations are peculiarly irrelevant in the application of tax measures now so largely directed toward intangible wealth."

See, also, Estate of Rogers v. Commissioner, 320 U.S. 410, 413-15 (1943) ; Helvering v. St. Louis Trust Co., 296 U.S. 39, 47 (1935) ; Klein v. United States, 283 U.S. 231, 234 (1931) ; Tyler v. U.S., 281 U.S. 497, 503 (1930). This principle has had its greatest expression in the income tax field. See, e.g., Heivering v. Clifford, 309 U.S. 331, 334 (1940); Gregory v. Helvering, 293 U.S. 465, $469-70$ (1935); Corliss v. Bowers, 281 U.S. 376, 378 (1930) ; U.S. v. Phellis, 257 U.S. 156, 168 (1921).

34. See text at notes 17 and 18 supra. See also note 30 supra.

35. Section 61 of the Internal Revenue Code (formerly $\$ 22(a)$ of the 1939 Code) has been interpreted as cutting athwart technical legal concepts of ownership; the courts have held that substantial economic dominion will be treated as the equivalent of legal ownership. See, e.g., Helvering v. Clifford, 309 U.S. 331, $335-7$ (1940); Burnet v. Wells, 289 U.S. 670, 677 (1933) ; Burnet v. Harmel, 287 U.S. 103, 110 (1932); Lucas v. Earl, 281 U.S. 111, 114 (1930); 6 Alertens, LAW of Feneral Ixcoure Taxation $\$ 37.17$ (Rev. ed, Henderson, 1948) and articles cited 6 id. at 493 n.55.

36. Helvering v. Safe Deposit \& Trust Co., 316 U.S. 56 (1942). Decedent in this case was the beneficiary of three trusts, each of which granted the beneficiary a general testamentary power of appointment over the trust property. The court rejected the government's argument that the combination of a life estate coupled with a general power of appointment constituted an "interest" within the meaning of $\S 302$ (a) (now $\S 2033$ of the Internal Revenue Code). It based its opinion on two facts: $\S 302$ (a) was rcenacted by Congress several times after the Supreme Court had indicated (but not held) that 
ments, ${ }^{37}$ does not preclude use of the test in the instant case. ${ }^{38}$ Moreover, the grounds adduced by the government for distinguishing prior decisions are

property subject to an unexercised general power of appointment would not be considered part of the estate of the donee of the power under $\$ 302(\mathrm{a})$; and Congress had stibscquently enacted a statute which taxed property passing under a general power of appointment but not property subject to an unexercised power. Revenue Act of 1918, § 402(f), 40 STAT. 1097 (1918).

The Court expressly stated that it was not rejecting the substantial ownership test in the estate tax field. "In declining to pass on this issue (whether the incidents of ownership held by the decedent were the equivalent of legal ownership) we do not reject the principle we have often recognized that the realities of the taxpaycr's cconomic interest, rather than the niceties of the conveyancer's art, should determine the power to tax. See Curry v. McCanless, 307 U.S. 357, 371, [(1939)] and cases there citcd. Nor do we deny the relevance of this principle as a guide to statutory interpretation wherc, unlike here, the language of a statute and its statutory history do not afford more specific indications of legislative intent. Helvering v. Clifford, 309 U.S. 331 [(1940]." Helvering v. Safe Deposit \& Trust Co., 316 U.S. 56, 58 n.1 (1942).

37. The first case following Safe Deposit, supra note 36 , which involved a substantial ownership contention on the part of the government was Estate of Gertrude Leon Roycr, 46 B.T.A. 1090 (1942), where decedent was a life beneficiary of a trust with an unrestricted right to invade the corpus. The Board cited Safe Deposit and held that the power to invade the corpus did not constitute an "interest" within the meaning of $\$ 302(\mathrm{a})$, Revenue Act of 1926, now INT. REv. CoDE of 1954, \& 2033. In Estate of Edward E. Bradley, 1 T.C. 518 (1943), aff'd sub nom. Helvering v. Washington Trust Co., 140 F.2d 87 (2d Cir. 1944), and Estate of Henry S. Downe, 2 T.C. 967 (1943), the Tax Court assumed for the purposes of argument that the substantial ownership doctrine was valid but held that the incidents of ownership retained in these cases were not equivalent to ownership.

In Commissioner v. Estate of Church, 335 U.S. 632 (1949), and Estate of Spicgel v. Commissioner, 335 U.S. 701 (1949), the Supreme Court upon reargument asked counsel what effect the Clifford case, supra note 35, had upon the trusts in question. However, the majority decisions were based solely on a reading of $\$ 811$ (c) (now INT. REv. Cope of 1954, § 2035). The Clifford case was mentioned by only Justice Burton who rejected the Clifford substantial ownership doctrine for estate taxation in his dissenting opinion in the companion case, Estate of Spiegel, supra at 712-18. Estate of Alcxander $K$. Sessoms, P-H 1949 TC MEM. DEc. If 49,286 (1949), was thus the first and only casc to state flatly that Safe Deposit had rejected the substantial ownership doctrine in the estate tax field.

The Schwartz, Haggett, and Davis cases, cited in note 20 supra, all relied on a finding that the decedent's rights were in effect nothing more than life estates coupled with general powers of appointment. They, therefore, fell squarely under Safc Dcposit; the applicability of the substantial ownership test was not discussed.

38. Since there is no statutory history which would show that Congress did not intend to treat a promise to pay to decedent's estate as the equivalent of a promise to pay decedent, the economic realities of the taxpayer's interest should govern. See note 36 supra. Indeed, what evidence there is of legislative intent would seem to show that Congress equated both kinds of promises. See notes 31 and 32 sipra and accompanying text. Moreover, soon after Safe Deposit was decided, Congress amended the statute to bring property subject to an unexercised power of appointment within the scope of the Estate Tax. Int. REv. Code of 1954, § 2041; Int. Rev. Code of 1939, § 811 (f). This would appear to be a legislative rejection of the ratio decidendi of the Safe Deposit holding. See note 36 sipra. 
sufficient to escape their effect. 39 The application of a substantial ownership test to Section 2033 would help eliminate inconsistency in the definition of ownership under income and estate taxation and would foreclose many opportunities for tax evasion now available in the estate tax field.t0

Furthermore, the fund should be taxable under Section 2041. .1 $^{\text {Although }}$ technically decedent may not have had a testamentary general power of appointment, ${ }^{42}$ as a practical matter she did control the devolution of the property. ${ }^{43}$ The committee reports which led to the 1942 amendment of this section

39. See notes 20 and 21 supra and accompanying text. The court placed great emphasis on the fact that the decedent's interest in the fund was "extinguished" by death. But clearly, it was no more extinguished in any real sense than the interest of an owner in fee. And the cases relied upon by the court all involve instances where the interests of the decedents were extinguishd, i.c., passed directly to third parties, and not through decedent's estate.

40. Much recent criticism has been directed at the inconsistency among the income, estate, and gift tax treatment of similar transactions. Greenbaum, The Clifiord Doctrine and the Estate Tax, 6 TAx L. Rev. 312 (1951); Adusory Counutte to the Treasury Departarent, Federat Estate and Gift Taxition; A Prorosal for Integration ast ConRetation with the Incone Tax 9-13 (1947); Griswold, A Plan for the Courdination of the Income, Estate and Gift Tax Provisions achth Respect to Trusts and Other Transfers, 56 HARv. L. Rev. 337 (1942).

There has also been criticism of the openings this affords for tax evasion. 1 PAUn, Federal Estate and Gift Taxation, $\$ 4.12$ (1942); id. $\S 4.12$ (Supp. 1946).

41. See notes 8 and 9 supra.

42. See the court's reasoning as stated in paragraph 2 of note 27 stupro. However, in a fact situation similar to the one in the instant case (property held in trust for $A$ for life, remainder to $A$ 's estate), a New York court held that the devise created a general power of appointment in $A$ and that the property did not become a part of $A$ 's estate, but rather that $A$ 's executors took the property merely as a "conduit" to transmit the property to the beneficiary chosen by $A$. Mfatter of Thompson, 274 App. Div. 49, 80 N.Y.S.2d 1 (1st Dept. 1948). The court pointed out that a power can be created by implication and held that it would look behind the literal meaning of the words used by the testator to his real intent; this, it found, was to give $A$ a general testamentary power of appointment.

43. This refers not to the right to name a contingent beneficiary, see note 27 supro, but rather to the power of disposition which the decedent had over the fund as part of her estate.

It is true that under a power of appointment the fund would have pissed directly from the insurance company to the appointee and not from the insurance company to the estate and then to the beneficiary. But as far as decedent's effective cuntrol over the disposition of the property is concerned, this makes no difference except for the minimal restraints upon the free will of a testator imposed by such statutes as those which prevent a testator from disinheriting his wife. The only other distinction is that in some states property passing under a general power of appointment is not subject to the debts of the estate of the donee of the power. Connor v. O'Hara, 1SS Mfd. 527, 53 A.2d 33 (1947); Terppe's Estate, $224 \mathrm{~Pa}$ 482, 73 Atl. 922 (1909). However. in many states, including Illinois, if the power is exercised in favor of a "volunteer" (one who talses for no valuable consideration) the property is thereby made an asset in equity for the payment of the donee's debts. Claims of creditors are then superior to those of the "volunteer" unless sufficient assets are otherwise available to meet creditors' claims. Shattucl: v. Burrage, 229 Mass. 448, 118 N.E. 889 (1918); See People v. Kaiser, 306 III. 313, 317, 
specifically state that it applies to all "powers which are in substance and effect powers of appointment regardless of the nomenclature used in creating the power and local property law connotations." 44 Here, the fund was ultimately distributed according to the decedent's specific instructions contained in the residuary clause of the will. ${ }^{45}$ It is this power to direct the course of property after one's death that the estate tax is designed to reach. ${ }^{40}$

Second National makes possible easy avoidance of estate taxation through the use of certain settlement options. Though the Second National fund would probably have been included in decedent's gross estate had the settlement option become effective after $1942,{ }^{47}$ omission or limitation of the right to name a contingent beneficiary would prevent inclusion 48 without substantially impairing the beneficiary's control over the fund. ${ }^{40}$ And use of a trust devise may be sustained to accomplish the same purpose. .0

137 N.E. 826,828 (1923). Moreover, subjection to the claims of creditors of the donce's estate is, if anything, an argument for inclusion in the donee's gross estatc. Sce the definition of a general power in INT. REv. CODE OF 1954, \& 2041, quoted in note 9 supra.

44. H.R. Rep. No. 2333, 77th Cong., 2d Sess. 160 (1942); SEN. REP. No. 1631, 77th Cong., 2d Sess. 232 (1942).

45. See note 27 supra.

46. Justice Frankfurter, speaking for the majority in Estate of Rogers, 320 U.S. 410, 413-14 (1943), stated as follows: "For the purpose of ascertaining the corpus on which an estate tax is to be assessed, what is decisive is what values were included in dispositions made by a decedent, values which but for such disposition could not have existed. That other values, whether worth more or less as to some of the beneficiaries, would have ripened into enjoyment if a testator had not exercised his privilege of transmitting property does not alter the fact that he and no one else did transmit the property which it was his to do with as he willed. And that is precisely what the federal estate tax hitsan exercise of the privilege of directing the course of property after a man's death." (Italics added)

47. Decedent's right to name a contingent beneficiary in Second National would secm to be a general power of appointment. See note 27 supra. If the power had been created after 1942, the fund would then have been taxable as property subject to a general power of appointment, even though this power was unexercised. See note 8 supra.

48. The right could be limited so as to constitute a special power of appointment. Property subject to such a power is not included in the decedent's gross estate whether exercised or not. A special power of appointment for the purposes of the estate tax is any power which cannot be exercised in favor of the decedent, his estate, his creditors, or the creditors of his estate. See notes 8 and 9 supra.

49. See notes 27, 42 , and 43 supra.

50. E.g., in trust for $A$ for life, remainder to $A$ 's estate. It seems clear that under the decision in the principal case, the trust remainder would not be included under $\S 2041$. The court held that person's power to control the disposition of his estate docs not give him a power of appointment over the property paid to his estate. There does not seem to be any reason why this reasoning should not apply where the property comes as a remainder interest as well as where the property passes to the estate under a contract. Int. Rev. CODE of 1954, \& 2033, formerly INT. Rev. CODE of 1939, § 811(a), provides that vested remainders, created by another's transfer, and held by the decedent, are includible in the gross estate. Estate of J. G. Frazier v. Commissioner, 162 F.2d 167 (3rd Cir. 1947) ; Estate of W. H. Kinney v. Commissioner, 80 F.2d 568 (9th Cir. 1935); cf. Estate of G. M. Henderson, 45 B.T.A. 1080 (1941). Since the Rule in Shelley's Case 
This decision also raises serious problems with regard to the marital deduction provisions ${ }^{51}$ of the estate tax. Prior to Second National it seemed clear that such settlement options and trusts qualified for the marital deduction." But a Treasury Regulation which states that such interests qualify only if they are included in the gross estate of the surviving spouse under Section $2033^{53}$ indicates that this may no longer be true. The validity of this regula-

is not applicable, see note 16 supra, the question under $\S 2033$ would essentially be the same as the one raised in the principal case: is a right, in this case a property right rather than a contractual right, in favor of a person's estate equivalent to a right in favor of the decedent for the purposes of the estate tax? The principal case appears to answer in the negative.

51. See note 52 infra.

52. INT. Rev. CoDE of 1954 § 2056, formerly INT. Rev. CoDE of 1939, § $\$ 11$ (c), provides: "For purposes of the tax imposed by section 2001, the value of the tamable estate shall, except as limited by subsections (b), (c), and (d), be determined by deducting frum the value of the gross estate an amount equal to the value of any interest in property which passes or has passed from the decedent to his surviving spouse. . ." Under the trust described in note $\mathbf{5 0}$ supra, the surviving spouse would have an equitable life estate. Such interests are covered by $\$ 2056$ (a). See SeN. REP. No. 1013, Pt. 2, See. 361, 80th Cong., 2d Sess. 16 (1948). And since upon termination the remainder interest passes to the spouse's estate, it is not excluded by the terminable interests exception in $\$ 2056(\mathrm{~b})$ which provides: "Where, on the lapse of time, on the occurrence of an event or contingency, or on the failure of an event or contingency to occur, an interest passing to the surviving spouse will terminate or fail, no deduction shall be allowed under this section with respect to such interest-(A) if an interest in such property passes or has passed (for less than an adequate and full consideration in money or money's worth) irom the decedent to any person other than such surviving spouse (or the cslote of such spouse); and (B) if by reason of such passing such person (or his heirs or assigns) may possess or enjoy any part of such property after such termination or failure of the interest so passing to the surviving spouse;" (italies added). See U.S. Treas. Reg. $105, \$ 81.47 \mathrm{a}(\mathrm{b})(2)$ (1949).

The above cited Regulation states that settlement options of the type involved in Second National qualify under $\$ 2056$ (with one reservation, however, see note 53 infra), and the Treasury has ruled that such an option qualifies. Telegraphic Ruling, CCH Est. \& GIFT TAX REP. If 2070.63 (1948). The Senate Report on \$ 811 (c) (re-enacted as $\$ 2056$ of the 1954 Code without relevant substantive change) states that the same rules applicable to other terminable interests apply to insurance settlement options. SEx. REP. No. 1013, 80th Cong., 2d Sess. 12 (1948). But the examples which it cites list almost every type of settlement option except that involved in Second National. There is strong evidence, however, that this was only an oversight, for though the original subsection dealing with life insurance omitted such settlement options, the subsection was amended immediately after passage to include them.

53. U.S. Treas. Reg. 105, $\S 81.47 a(b) 2$ (1949) : “. . . However, with respect to the foregoing illustrations which involve interests which are distributable to IV's estate (or to her executors or administrators) in the event of the termination of a trust or of a precedent interest at or after her death, it should be noted that the interest so distributable is to be considered as having passed from $\mathrm{H}$ to $\mathrm{W}$ only if such interest would be includible in her gross estate under 811 (a) [\$ 2033 of the 1954 Code]."

In light of the decision in Second National, roughly three courses are open to the Treasury: (1) to accept Second National and refuse to consider such settlement untiuns and trusts as qualifying under $\$ 2056$; (2) to ignore or refuse to accept Sccond National 
tion and the tax consequences to those estate plans drawn up in reliance on prior interpretations of Section 2056 will be a source of confusing litigation for some time to come. ${ }^{54}$ Medieval property concepts should not be allowed to afford means for tax evasion and to create confusion in the interpretation of the marital deduction provisions.

and continue to consider such trusts and settlement options as qualifying; or (3) to refuse to accept Second National and still refuse to consider such trusts and settlement options as qualifying. It is unlikely that the Treasury will accept Second National particularly since Congress undoubtedly intended $\$ 2056$ to cover such interests. Sec note 52 supra. But if the second alternative is adopted and the courts follow Sccond National, a testator spouse will be able to obtain the benefits of the marital exemption in his own estate and still avoid taxation on the property upon the death of the surviving spousc. Therefore it is probable the Treasury will follow the third course.

54. The Commissioner is probably not bound by his ruling with regard to settlement options, see note 52 supra, even though the particular taxpayer to whom it was given acts in reliance on it. Cf. Couzens v. Commissioner, 11 B.T.A. 1040 (1928). But $c f$. Woodworth v. Kales, 26 F.2d 178 (6th Cir. 1928). And see H.S.D. Co. v. Kavanaugh, 191 F.2d 831 (6th Cir. 1951); Manning, The Application of the Doctrine of Estoppcl Against the Government in Federal Tax Cases, 30 N.C.L. Rev. 356, 367-80 (1952); Newman, Should Official Advice be Reliable?-Proposals as to Estoppel and Relatcl Doctrines in Administrative Laze, 53 Col. L. REv. 374 (1953). Whether or not the Treasury is bound, it almost never revokes a ruling as to the taxpayer to whom it was issued. But there is still the question of whether the ruling will be revoked as to other taxpayers who may have relied on the ruling. In I.R. Mimeo. No. 100 (1953), Bureau personnel are cautioned to "consider the effect of subsequent legislation, regulations, court decisions and rulings" (italics supplied) in applying rulings to other taxpayers.

The validity of the proviso in U.S. Treas. Reg. 105, $\S 81.47 \mathrm{a}$ (b) (2) (1949), see note 53 supra, may also be questioned if the Treasury attempts to exclude such settlement options and trusts from the coverage of the marital deduction. The Regulation requirement that the interest so passing must be includible in the surviving spouse's gross estate is nowhere specifically stated in $\S 2056$. Therefore it is possible to argue that such interests come under the language of the statute and qualify, despite clear Congressional intent to the contrary, whether or not they are includible in the surviving spouse's gross estate. If the requirement is successfully challenged and Second National is followed, a broad avenue for tax evasion will be opened. 